\title{
Pendekatan Problem Solving dengan Strategi Metakognitif untuk Meningkatkan Kemampuan Pemecahan Masalah Matematika Siswa
}

\author{
Idayu Rifki Anjani, a) \\ ${ }^{1}$ Universitas PGRI Rongolawe \\ a) idayurifky@gmail.com
}

\begin{abstract}
The purpose of this study was to describe the increase in mathematical problem solving abilities and students response during the learning process with apply a problem solving approach with metacognitive strategies. This research is a classroom action research consisting of 3 cycles. The instrument used is a test of mathematical problem solving skills and student response questionnaire. The results of the study concluded that the ability of mathematical problem solving in the application of problem solving approaches with metacognitive strategies has increased. This can be seen from the average test of mathematical problem solving ability from cycle I is 67 , cycle II is 70 and cycle III is 82 . While the response of students is included in the effective criteria, with a percentage of positive responses $94 \%$ and a negative response percentage of $6 \%$.
\end{abstract}

Keywords: problem solving approaches, metacognitive strategies, problem solving skills

\begin{abstract}
Abstrak. Tujuan dari penelitian ini adalah untuk menggambarkan peningkatan kemampuan pemecahan masalah matematika dan respon siswa selama proses pembelajaran dengan menerapkan pendekatan pemecahan masalah dengan strategi metakognitif. Penelitian ini merupakan penelitian tindakan kelas yang terdiri dari 3 siklus. Instrumen yang digunakan adalah tes keterampilan pemecahan masalah matematika dan angket respon siswa. Hasil penelitian menyimpulkan bahwa kemampuan pemecahan masalah matematika dalam penerapan pendekatan pemecahan masalah dengan strategi metakognitif telah meningkat. Hal ini dapat dilihat dari rata-rata tes kemampuan pemecahan masalah matematis dari siklus I adalah 67, siklus II adalah 70 dan siklus III adalah 82. Sedangkan respon siswa termasuk dalam kriteria efektif, dengan persentase tanggapan positif $94 \%$ dan persentase respons negatif $6 \%$.
\end{abstract}

Kata kunci: pendekatan problem solving, strategi metakognitif, keterampilan pemecahan masalah 


\section{PENDAHULUAN}

Matematika merupakan salah satu cabang ilmu yang implementasinya berkaitan erat dalam kehidupan. Peranan matematika dalam kehidupan adalah sarana untuk membentuk berpikir dalam mengkaji sesuatu secara logis dan sistematis (Abduloh, Karomah, \& Hidayati, 2018). Oleh karena itu matematika diwajibkan diajarkan pada jenjang pendidikan dari SD, SMP hingga SMA. Dalam dunia pendidikan, guru merupakan salah satu faktor penting yang berperan untuk membimbing dan memotivasi siswa agar siswa tersebut mampu menerima serta memahami materi yang telah disampaikan serta bertujuan agar siswa lebih aktif dalam proses pembelajaran (Gunawan \& Putra, 2019).

Berdasarkan hasil pengamatan yang dilakukan oleh peneliti pada siswa kelas VII A SMP Nurul Anwar Montong bahwa proses pelaksanaan pembelajaran matematika selama ini masih terkesan monoton, sehingga siswa kurang mampu mengoptimalkan kemampuan mereka yaitu dalam proses pembelajaran matematika khususnya dalam memecahkan masalah matematika. Pada umumnya kemampuan pemecahan masalah matematika siswa yaitu dalam hal informasi mengenai yang diketahui dan yang ditanyakan serta masih kesulitan dalam menentukan langkah-langkah yang dibutuhkan untuk memecahkan masalah matematika. Selain itu, proses pembelajaran yang berlangsung masih cenderung berpusat pada guru.

Pendekatan problem solving menekankan pada pemahaman terhadap permasalahan, kemudian mencari penyelesaian dan menyelesaikan permasalahan serta melakukan evaluasi kembali penyelesaian yang di lakukan. Penggunaan pendekatan problem solving dalam kegiatan pembelajaran dengan jalan melatih siswa menghadapi berbagai masalah baik masalah perorangan maupun masalah kelompok untuk dipecahkan sendiri atau secara bersama-sama (Wulansari, Putra, Rusliah, \& Habibi, 2019).

Menurut Polya langkah-langkah pendekatan problem solving terdiri atas 4 langkah. Langkah I: Understanding the problem (memahami permasalahan), siswa diharuskan untuk memahami terlebih dahulu masalah yang sedang dihadapinya, tentu hubungannya berlanjut pada apa sebenarnya yang diminta oleh soal. Langkah II: Devising a plan (merencanakan penyelesaian), siswa akan mulai menyusun langkah-langkah apa yang akan digunakannya dalam menyelesaikan soal. Langkah III: Carrying out the plan (melaksanakan rencana), siswa mulai menyelesaikan masalah/soal yang dihadapinya dengan bantuan langkah-langkah atau cara yang telah mereka persiapkan sebelumnya. Langkah IV: Looking back (melihat kembali), pada tahap inilah memungkinkan siswa memperbaiki proses yang telah ia kerjakan jika terjadi suatu kesalahan.

Selain menerapkan pendekatan pembelajaran, peneliti memilih strategi metakognitif yang diharapkan dapat meningkatkan dan membantu siswa menggunakan proses berpikir untuk mengembangkan aktivitas dalam memecahkan masalah matematika. Metakognitif merupakan kesadaran atau pengetahuan seseorang terhadap proses dan hasil belajar berpikirnya (kognitif) serta kemampuan dalam mengontrol dan mengevaluasi proses kognitif tersebut. Aspek-aspek metakognitif akan sangat membantu siswa dalam memahami materi yang dipelajari melalui aktivitas pembelajaran yang baik (Syaifudin, 2016).

Menurut Blakey \& Spence (dalam Permata, 2012) mengemukakan strategi-startegi atau langkah-langkah untuk meningkatkan keterampilan metakognitif sebagai berikut. Langkah I, mengidentifikasi "apa yang kau ketahui" dan "apa yang kau tidak ketahui", Memulai aktivitas pengamatan, siswa perlu membuat keputusan yang disadari tentang pengamatan mereka. Langkah II, berbicara tentang berpikir (talking about thinking), Selama membuat perencanaan dan 
memecahkan masalah, guru boleh "menyuarakan pikiran", sehingga siswa dapat ikut mendemonstrasikan proses berpikir. Langkah III, membuat jurnal berpikir (keeping thinking journal), cara lain untuk mengembangkan metakognisi adalah melalui penggunaan jurnal atau catatan belajar. Jurnal ini berupa buku harian dimana setiap siswa merefleksi berpikir mereka, membuat catatan tentang kesadaran mereka terhadap kedwiartian (ambiguities). Langkah IV, membuat perencanaan dan regulasi-diri, siswa harus mulai bekerja meningkatkan responsibilitas untuk merencanakan dan meregulasi belajarnya. Langkah $\mathrm{V}$, melaporkan kembali proses berpikir (debriefing thinking process), memfokuskan diskusi siswa pada proses berpikir untuk mengembangkan kesadaran tentang strategi yang dapat diaplikasikan pada situasi belajar yang lain. Langkah VI, evaluasi-diri (self-evaluation), mengarahkan pengalaman-pengalaman evaluasi-diri dapat diawali melalui pertemuan individual dan daftar-daftar yang berfokus pada proses berpikir. Secara bertahap, evaluasi-diri akan lebih banyak diaplikasikan secara independen. Penelitian ini sejalan dengan penelitian yang dilakukan oleh Iruludin (2016) dengan problem solving disimpulkan dapat meningkatkan penalaran matematis siswa. Untuk penilaian kemampuan pemecahan masalah, guru dapat menggunakan modul (Kurniawan, Rusdi \& Marzal, 2019).

Adapun langkah-langkah pembelajaran menggunakan Pendekatan Problem Solving dengan Strategi Metakognitif adalah sebagai berikut:

Tabel 1. Langkah-langkah Pendekatan Problem Solving dengan Strategi Metakognitif

\begin{tabular}{|c|c|c|c|}
\hline $\begin{array}{c}\text { Tahap } \\
\text { Pembelajaran }\end{array}$ & $\begin{array}{c}\text { Pendekatan } \\
\text { Problem Solving }\end{array}$ & $\begin{array}{c}\text { Strategi } \\
\text { Metakognitif }\end{array}$ & Aktivitas Guru \\
\hline \multirow{5}{*}{ Pendahuluan } & & & - Guru mengucapkan salam \\
\hline & & & - Guru menyampaikan tujuan pembelajaran \\
\hline & & & - Guru memberikan motivasi kepada siswa \\
\hline & & & - Guru menjelaskan langkah-langkah pembelajaran \\
\hline & & & $\begin{array}{l}\text { - Guru meminta siswa berkelompok sesuai yang telah } \\
\text { ditentukan. }\end{array}$ \\
\hline \multirow{9}{*}{ Inti } & \multirow[t]{7}{*}{$\begin{array}{l}\text { Memahami } \\
\text { masalah }\end{array}$} & \multirow{7}{*}{$\begin{array}{l}\text { - Mengidentifikasi } \\
\text { apa yang kau } \\
\text { ketahui" dan "apa } \\
\text { yang kau tidak } \\
\text { ketahui" } \\
\text { - Berbicara } \\
\text { tentang berpikir }\end{array}$} & $\begin{array}{l}\text { - Guru memberikan permasalahan kepada siswa berupa } \\
\text { LKS }\end{array}$ \\
\hline & & & $\begin{array}{l}\text { - Guru meminta siswa mengamati permasalahan untuk } \\
\text { membuat keputusan terkait dengan pengetahuan yang } \\
\text { dimilikinya (memverifikasi, mengklarifikasi dan }\end{array}$ \\
\hline & & & $\begin{array}{l}\text { mengembangkan atau mengubah pernyataan awal } \\
\text { dengan informasi yang akurat). }\end{array}$ \\
\hline & & & $\begin{array}{l}\text { - Guru membimbing siswa dalam mengkaji } \\
\text { permasalahan }\end{array}$ \\
\hline & & & $\begin{array}{l}\text { - Guru mengungkapkan pikirannya dengan mengajukan } \\
\text { pertanyaan agar siswa dapat mendemonstrasikan proses } \\
\text { berpikirnya. }\end{array}$ \\
\hline & & & $\begin{array}{l}\text { - Guru menginstruksikan siswa untuk berpasangan } \\
\text { dengan teman sebangkunya. }\end{array}$ \\
\hline & & & $\begin{array}{l}\text { - Guru menyuruh siswa bersama pasangannya saling } \\
\text { membicarakan masalah di LKS dan mendeskripsikan } \\
\text { proses berpikirnya. }\end{array}$ \\
\hline & \multirow[t]{2}{*}{$\begin{array}{l}\text { Merencanakan } \\
\text { penyelesaian }\end{array}$} & \multirow{2}{*}{$\begin{array}{l}\text { Membuat } \\
\text { perencanaan dan } \\
\text { regulasi-diri }\end{array}$} & $\begin{array}{l}\text { - Guru membantu dan membimbing siswa dalam } \\
\text { mencari berbagai alternatif pemecahan masalah }\end{array}$ \\
\hline & & & $\begin{array}{l}\text { - Guru memberikan kebebasan siswa untuk membuat } \\
\text { perencanaan dan pengaturan diri mengenai langkah } \\
\text { atau strategi apa yang harus digunakan dalam } \\
\text { menyelesaikan masalah. }\end{array}$ \\
\hline
\end{tabular}




\begin{tabular}{|c|c|c|c|}
\hline $\begin{array}{c}\text { Tahap } \\
\text { Pembelajaran } \\
\end{array}$ & $\begin{array}{c}\text { Pendekatan } \\
\text { Problem Solving } \\
\end{array}$ & $\begin{array}{c}\text { Strategi } \\
\text { Metakognitif } \\
\end{array}$ & Aktivitas Guru \\
\hline & \multirow[t]{3}{*}{$\begin{array}{l}\text { Melaksanakan } \\
\text { penyelesaian }\end{array}$} & \multirow{3}{*}{$\begin{array}{l}\text { Membuat jurnal } \\
\text { berpikir (keeping } \\
\text { thinking journal) }\end{array}$} & $\begin{array}{l}\text { - Guru membimbing siswa dalam melaksanakan } \\
\text { pemecahan masalah secara bertahap }\end{array}$ \\
\hline & & & $\begin{array}{l}\text { - Guru menyediakan jurnal atau catatan belajar kepada } \\
\text { siswa yang dilengkap dengan instruksi pengisiannya }\end{array}$ \\
\hline & & & $\begin{array}{l}\text { - Guru menyuruh siswa merefleksikan berpikir mereka, } \\
\text { membuat catatan tentang kesadaran terhadap sesuatu } \\
\text { yang ambigu dan tidak konsisten, dan komentar tentang } \\
\text { bagaimana mereka menghadapi kesulitan dalam } \\
\text { menyelesaikan masalah ke dalam jurnal atau catatan } \\
\text { belajar yang telah disediakan. }\end{array}$ \\
\hline & \multirow{8}{*}{$\begin{array}{l}\text { Memeriksa } \\
\text { kembali } \\
\text { penyelesaian }\end{array}$} & \multirow{8}{*}{$\begin{array}{l}\text { - Melaporkan } \\
\text { kembali proses } \\
\text { berpikir } \\
\text { (Debriefing } \\
\text { thinking process) } \\
\text { - Evaluasi-diri } \\
\text { (Self-evaluation) }\end{array}$} & - Guru membimbing siswa melakukan pengecekan \\
\hline & & & terhadap hasil penyelesaian soal \\
\hline & & & - Guru meminta siswa memereviu aktivitas belajarnya. \\
\hline & & & - Guru memberikan kesempatan siswa untuk \\
\hline & & & mempresentasikan hasil dari penyelesaian masalahnya. \\
\hline & & & $\begin{array}{l}\text { - Guru meminta siswa lain dengan strategi penyelesaian } \\
\text { yang berbeda untuk mempresentasikan hasilnya. }\end{array}$ \\
\hline & & & $\begin{array}{l}\text { - Guru meminta siswa mengevaluasi keberhasilan, } \\
\text { membuang strategi-strategi yang tidak tepat, } \\
\text { mengidentifikasi strategi yang dapat digunakan dan } \\
\text { mencari pendekatan alternatif. }\end{array}$ \\
\hline & & & $\begin{array}{l}\text { - Guru mengarahkan pengalaman-pengalaman siswa } \\
\text { untuk menyelesaikan permasalahan lain secara } \\
\text { individu. }\end{array}$ \\
\hline \multirow[t]{2}{*}{ Penutup } & & & $\begin{array}{l}\text { - Guru bersama siswa mereview kegiatan kegiatan } \\
\text { pembelajaran }\end{array}$ \\
\hline & & & - Guru menutup pembelajaran dengan salam \\
\hline
\end{tabular}

\section{METODE}

Penelitian ini mengguakan jenis penelitian tindakan kelas (PTK), tujuan penelitian ini adalah untuk mendeskripsikan peningkatan kemampan pemecahan masalah matematika siswa dan respon siswa selama proses pembelajaran dengan menerapkan pendekatan problem solving dengan strategi metakognitif pada materi bangun datar segiempat (persegi panjang, persegi dan jajar genjang) kelas VII A SMP Nurul Anwar Montong tahun pelajaran 2017/2018. Subjek dari penelitian ini adalah siswa kelas VII A SMP Nurul Anwar Montong tahun ajaran 2017/2018 semester genap yang berjumlah 28 siswa.

Teknik pengumpulan data dalam penelitian ini adalah teknik tes dan teknik angket. Metode tes digunakan untuk menghitung kemampuan pemecahan masalah matematika siswa, metode angket untuk menghitung respon siswa terhadap pembelajaran yang diterapkan. Sedangkan instrumen yang digunakan adalah tes kemampuan pemecahan masalah matematika siswa dan lembar angket respon siswa. Lembar tes kemampuan pemecahan masalah matematika siswaberisi 4 indikator pemecahan masalah dari Polya dan berupa tes uraian yang terdiri dari 2 soal, sedangkan lembar angket respon siswa terdiri dari 10 pertanyaan. 


\section{HASIL DAN PEMBAHASAN}

\section{Tes Kemampuan Pemecahan Masalah Matematika Siswa}

Untuk mendeskripsikan peningkatan kemampuan pemecahan masalah matematika siswa setelah diterapkan pendekatan problem solving dengan strategi metakognitif dalam tiga siklus dapat dilihat pada Tabel 2.

Tabel 2 Perbandingan Hasil Tes Kemampuan Pemecahan Masalah Matematika

\begin{tabular}{ccccc}
\hline Siklus & Siswa yang Tuntas & $\begin{array}{c}\text { Siswa yang } \\
\text { Tidak Tuntas }\end{array}$ & Rata-rata & $\begin{array}{c}\text { Ketuntasan Belajar } \\
\text { Klasikal (\%) }\end{array}$ \\
\hline Pra Siklus & 8 & 20 & 66 & 29 \\
\hline Siklus I & 11 & 17 & 67 & 40 \\
\hline Siklus II & 19 & 9 & 70 & 69 \\
\hline Siklus III & 26 & 2 & 82 & 93 \\
\hline
\end{tabular}

Berdasarkan Tabel 2 ketuntasan belajar siswa dari siklus I, siklus II dan siklus III mengalami peningkatan. Begitu juga sebaliknya jumlah siswa yang tidak tuntas mengalami penurunan. Persentase ketuntasan klasikal pada prasiklus adalah $29 \%$, pada siklus I adalah $40 \%$, pada siklus II adalah 69\% dan pada siklus III mengalami peningkatan menjadi 93\%. Pada siklus III ini peningkatan hasil belajar klasikal termasuk kategori efektif. Sedangkan rata-rata hasil belajar siswa pra siklus adalah 66, siklus I 67, siklus II 70 dan siklus III mencapai 93. Berdasarkan pengamatan yang dilakukan bahwa penerapan pendekatan problem solving dengan strategi metakognitif dapat meningkatkan kemampuan pemecahan masalah matematika siswa. Ini sejalan dengan hasil penelitian Elita, Habibi, Putra \& Ulandari (2019) yang berkesimpulan bahwa pendekatan problem solving dengan strategi metakognitif mampu meningkatkan kemampuan pemecahan masalah matematika siswa.

\section{Respon Siswa}

Untuk mendeskripsikan respon siswa selama diterapkan pendekatan problem solving dengan strategi metakognitif dalam tiga siklus dapat dilihat pada Tabel 3.

Tabel 3 Respon Siswa terhadap Penerapan Pendekatan Problem Solving dengan Strategi Metakognitif

\begin{tabular}{clcc}
\hline No. & \multicolumn{1}{c}{ Pernyataan } & Ya & Tidak \\
\hline 1. & Proses pembelajaran mendorong saya untuk menemukan ide-ide baru & $93 \%$ & $7 \%$ \\
\hline 2. & Proses pembelajaran membuat saya lebih merasa termotivasi & $90 \%$ & $10 \%$ \\
\hline 3. & Proses pembelajaran membuat saya menjadi lebih aktif dalam kegiatan belajar di kelas & $96 \%$ & $4 \%$ \\
\hline 4. & Saya lebih memahami materi dalam pembelajaran ini & $93 \%$ & $7 \%$ \\
\hline 5. & Saya lebih rajin mengerjakan latihan soal dalam pembelajaran & $90 \%$ & $10 \%$ \\
\hline 6. & Proses pembelajaran dapat mengeksplorasi diri saya sendiri & $93 \%$ & $7 \%$ \\
\hline 7. & Saya lebih trampil menyelesaikan masalah di dunia nyata terkait pembelajaran & $96 \%$ & $4 \%$ \\
\hline m. & Proses pembelajaran membuat pembelajaran matematika lebih menarik kaitannya & & \multirow{2}{*}{ dengan masalah di dunia nyata } \\
\hline 9. & Proses pembelajaran dapat membuat saya berpikir secara mendalam & $96 \%$ & $4 \%$ \\
\hline 10. & Proses pembelajaran dapat membuat saya meningkatkan kreativitas saya & $96 \%$ & $4 \%$ \\
\hline & & $93 \%$ & $7 \%$ \\
\hline
\end{tabular}

Kualifikasi Kefektifan

Efektif

Available online at journal homepage: http://ejournal.iainkerinci.ac.id/index.php/edumatika Email: edumatika@iainkerinci.ac.id 
Berdasarkan Tabel 3 dan dapat dilihat rata-rata persentase respon positif adalah $94 \%$ dan respon negatif adalah $6 \%$. Ditinjau dari persentase yang didapatkan respon siswa dikatakan positif dan kategori efektif dikarenakan persentase respon siswa terhadap penerapan pendekatan problem solving dengan strategi metakognitif lebih dari atau sama dengan $85 \%$.

\section{KESIMPULAN}

Berdasarkan hasil kegiatan pembelajaran dengan pendekatan problem solving dengan strategi metakognitif yang telah dilaksanakan dalam tiga siklus dan erdasarkan hasil analisis serta pembahasan maka dapat disimpulkan bahwa: (1) kemampuan pemecahan masalah matematika siswa setelah diterapkan pendekatan problem solving dengan strategi metakognitif mengalami peningkatan dengan nilai rata-rata pada siklus I 67, siklus II 70 dan siklus III mencapai 82. Persentase ketuntasan klasikal pada siklus I adalah 40\%, pada siklus II adalah $69 \%$ dan siklus III mengalami peningkatan menjadi 93\%; (2) respon siswa setelah diterapkan pendekatan problem solving dengan strategi metakognitif siswa mwemberikan respon positif. Hal ini ditunjukkan dari hasil perhitungan angket respon siswa sebesar $94 \%$ menyatakan berminat dalam kegiatan pembelajaran dan merespon positif untuk tiap pilihan pertanyaan sedangkan respon negatif adalah $6 \%$.

\section{DAFTAR RUJUKAN}

Abduloh, U., Karomah, N., \& Hidayati, S. (2018, February). Peningkatan Kemampuan Pemecahan Masalah Matematika dalam Soal Literasi Matematika melalui Model Creative Problem Solving Kelas VIII H SMPN 9 Semarang. In PRISMA, Prosiding Seminar Nasional Matematika, 1, 774-780.

Elita, G. S., Habibi, M., Putra, A., \& Ulandari, N. (2019). Pengaruh Pembelajaran Problem Based Learning dengan Pendekatan Metakognisi terhadap Kemampuan Pemecahan Masalah Matematis. Mosharafa: Jurnal Pendidikan Matematika, 8(3), 447-458.

Gunawan, R. G., \& Putra, A. (2019). Pengaruh Strategi Belajar Aktif Sortir Kartu Terhadap Kemampuan Pemecahan Masalah Matematis. Jurnal Cendekia: Jurnal Pendidikan Matematika, 3(2), 362-370.

Iruludin, M. (2016). Penerapan Model Pembelajaran Kooperatif Tipe TGT dengan Pendekatan Problem Solving dalam Meningkatkan Penalaran Matematis Siswa. Skripsi. Tuban: UNIROW.

Kurniawan, A., Rusdi, M., \& Marzal, J. (2019). Pengembangan Modul Pedoman Guru dalam Mendesain Instrumen Penilaian Matematika Berbasis Pemecahan Masalah Matematika. Edumatika: Jurnal Riset Pendidikan Matematika, 2(1), 15-22. doi:10.32939/ejrpm.v2i1.259

Permata, S. P. (2012). Penerapan Strategi Metakognitif dalam Pembelajaran Matematika Siswa Kelas X SMA Negeri 2 Padang. Jurnal Pendidikan Matematika, 1(1).

Wulansari, T., Putra, A., Rusliah, N., \& Habibi, M. (2019). Pengaruh Model Pembelajaran Berbasis Masalah pada Materi Statistika terhadap Kemampuan Penalaran Statistik Siswa. AKSIOMA: Jurnal Matematika dan Pendidikan Matematika, 10(1), 35-47. 